\title{
Assessing the Impacts of Climate Variability on Livelihood Assets in Marigat and Mogotio Sub-County, Baringo County, Kenya
}

\author{
Ezenwa, Lilian I.. ${ }^{*}$, Ibe, Geraldine $0 .^{2}$, Ochor $\mathrm{N}^{2}{ }^{2}$ \\ and Ogbonna Onyekachi A. ${ }^{1}$ \\ ${ }^{1}$ Department of Environmental Management and Toxicology, Michael Okpara University of Agriculture \\ Umudike, Abia State, Nigeria. \\ ${ }^{2}$ Department of Forestry \& Environmental Management, Michael Okpara University of Agriculture \\ Umudike, Abia State, Nigeria.
}

\section{Authors' contributions}

This work was carried out in collaboration between all authors. Author ELI designed the study and wrote the first draft of the manuscript. Author IGO handled the statistical analyses and interpretation. Authors ON and OOA managed the analyses of the study and the literature searches. All authors read and approved the final manuscript.

\section{Article Information}

DOI: 10.9734/AJGR/2018/v1i124670

Editor(s):

(1) Xu Chong, Professor, Institute of Geology, China Earthquake Administration, China (2) Badiora Adewumi Israel, Department of Urban and Regional Planning, Wesley University, Nigeria.

Reviewers:

(1) Victoria Jovin Mugula, Jordan University College, Tanzania.

(2) Kisaka Masika Oscar, University of Kabiang, Kenya.

(3) Cornelius Okello, Machakos University, Kenya.

Complete Peer review History: http://www.sciencedomain.org/review-history/24851

Original Research Article

Received $16^{\text {th }}$ February 2018

Accepted $24^{\text {th }}$ April 2018

Published 29 ${ }^{\text {th }}$ May 2018

\begin{abstract}
This study assessed the various effects of variability in climatic conditions to the means of livelihood and assessed the impacts of climatic conditions like temperature and rainfall on the livelihood assets of the indigenes of Baringo County, which include: livestock, health, agricultural and tree crops, water bodies. A multi-stage sampling technique was applied, using both quantitative and qualitative methods of data collection. Primary data was collected using a well-structured questionnaire while secondary data was obtained from the Meteorological Department Nairobi, Kenya. Data obtained were analysed using frequency distribution, trend analysis, percentage and means, as well as
\end{abstract}


multiple regression analysis. A total of 338 respondents were sampled. Variability in rainfall and temperature significantly affected the livelihood assets of the rural populace. It was observed that $78.7 \%$ of the respondents in are informed of climate change, mostly through the media (34.62\%). Climate variability to a high extent results in drought $(X=3.78)$, crop pests and diseases $(X=3.65)$, livestock pests and diseases $(X=3.70)$ and cases of human diseases $(X=4.01) .94 .38 \%$ of the rural populace in Baringo County experience food insecurity due to climate variability. Climate variability in temperature and rainfall affected general economic activities of the counties at every level of statistical significance even as high variability in climate conditions affected the rural population in Kenya majorly in the areas of drought $60 \%$, the quantity of meal $31.7 \%$ and income $29.6 \%$. This study, therefore, concluded that climate variables will affect the ecosystems and most likely will alter the economic and physical factors including income, general health and well-being of the rural populace in Baringo County, Kenya.

Keywords: Climate variability; livelihood; information.

\section{INTRODUCTION}

Africa is vulnerable to impacts of climate change and variability, despite the area contributing only $<3 \%$ of the world's total greenhouse gas emission [1]. Climate variability has considerably impeded Africa's development and it is expected that climate variability will increase and climate extremes will become more intense or more frequent [2]. According to Antwi-Agyei et al. (2014), climate variability poses a significant threat to many sectors of sub-Saharan Africa's economy and agricultural sector being dependent on rain-fed cultivation.

Climate variability refers to a measure of the frequency of changes in the values of climate variables and their range over a given period of time [4]. It is one of the pervasive stresses that individuals and communities in rural areas have to cope with. The impact of different types of climate variability range from minor to major and will depend on both the household and the environmental characteristics. The impacts can be both direct and indirect. For example, a stress, such as delayed onset of rain, has the potential to affect not only livestock and crops but also education, nutrition and social networks. The focus on different assets and strategies enables some of the indirect impacts to be assessed [5].

In Sub-saharan Africa, as a result of the continued deterioration in agricultural production occasioned by climate variation, many households tend to depend on other livelihood choices than purely crop production and animal production. Livelihood activities are the alternative socio-economic activities that the household member engages in to provide for their needs. Households engage in both farm and non-farm (non-agricultural) livelihood activities such as crop production, animal rearing, petty trading in order to generate additional income for survival and cope with this harsh and difficult environment $[6,7]$. Livelihood activities of the households' are related to their endowment of social, human, financial, physical and natural assets [8].

Climate variability has heavily impacted on livestock production, which is the main source of livelihood to most of the rural populace in Baringo County. The impacts have affected various aspects of their livelihood, including livestock production (feed quantity and quality), crop production, animal and rangeland biodiversity, distribution of diseases, management practices and production systems changes among others [9]. Rural households pursue a wide range of livelihood strategies in developing countries. Some households diversify their livelihood strategies while others rely on one or more activities. Livelihood capital provides a substantial contribution to the benefit of many rural dwellers. However, the possession and degree of reliance on livelihood capital differ across households [10].

This study was carried out to provide important information towards understanding the effects of climate variability on livelihood assets (such as land for agriculture, livestock, maize farming, bee keeping, poultry farming, charcoal production, fruits - especially watermelon etc), assess the extent of effect of climate variability in the environment and determine the sources of information on climate variability in Baringo County, Kenya. 


\section{STUDY AREA}

The study was carried out between March and July 2017 in Marigat and Mogotio sub-county
(Baringo County) located in former Rift Valley Province, North-West Kenya. Baringo is one of the 47 counties in Kenya, situated in the Rift Valley region. It borders Turkana and Samburu

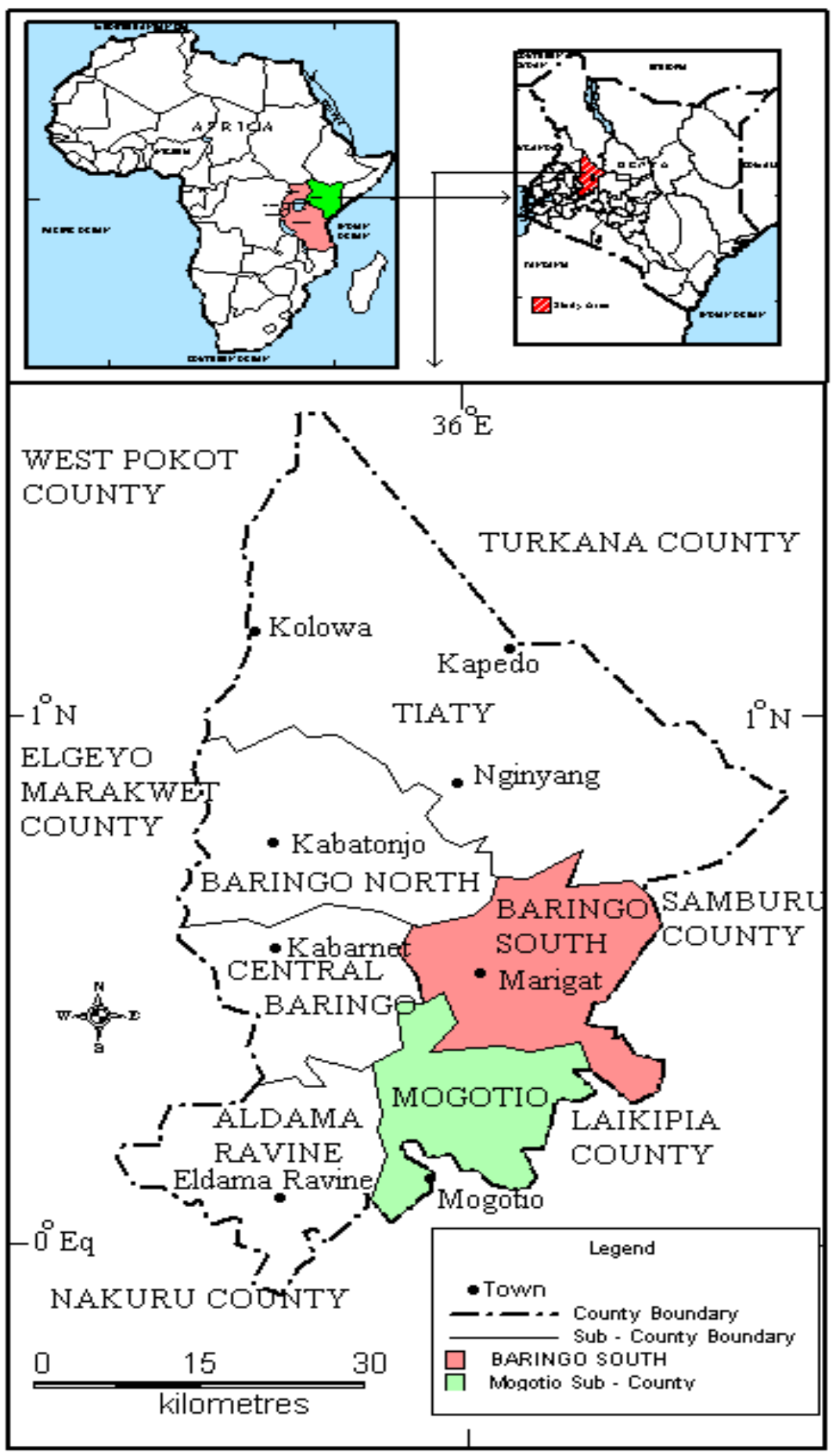

Map 1. Map of Baringo County showing Marigat and Mogotio as the study areas 
counties to the North, Laikipia to the East, Nakuru and Baringo to the South, Uasin Gishu to the Southwest, and Elgeyo - Marakwet and West Pokot to the West. With an area of $11,075.3 \mathrm{~km}^{2}$, Baringo County has an estimated population of 555,561 [11]. It is a semi-arid area situated at an average altitude of $900 \mathrm{~m}$ above the sea level and lies between latitude $00^{\circ} 26^{\prime}-00^{\circ} 32^{\prime} \mathrm{N}$ and longitude $36^{\circ} 00^{\prime}-36^{\circ} 09^{\prime} \mathrm{E}$ and. It is located within agro-climatic zone IV and $\mathrm{V}$ [12]. The area has a mean temperature of about $32.8^{\circ} \mathrm{C} \pm 1.6^{\circ} \mathrm{C}$ with annual average rainfall of $512 \mathrm{~mm}$ occurring in two seasons: March to August and November to December.

\subsection{Research Design and Data Collection}

In this study, a multi-stage sampling technique was applied, using both quantitative and qualitative approaches. Primary data was collected using a well-structured questionnaire while secondary data (31-year-old climatic data) was obtained from the Kenya Meteorological Department. The validity of the semi-structured questionnaire was pre-tested before it was used in collecting data from the sampled communities and villages. The target population comprised of household heads, either the father or mother or any adult person in charge (aged 18 years and above) of the household. The qualitative data was obtained using focus group discussions (FGDs). Focus group discussions were held in different villages to elicit information concerning climate variability impact of drought, livelihood activities as it relates to men and women in the study area. These served as a guide in counterchecking the information that was supplied by each male headed and female headed household in the study area.

Data obtained were analysed using descriptive statistics such as frequency distribution, trend analysis, percentage and means; and inferential statistics such as multiple regression analysis. These data obtained was compiled, processed and analysed using SPSS version 23 and E view 9 computer statistical software. The ordinary least square multiple regression analysis used in the study is model as;

$$
Y_{i}=\beta_{0}+\beta_{1} X_{1}+\beta_{2} X_{2}+e_{i}
$$

Where,

$$
\mathrm{Y}_{\mathrm{i}}=\begin{aligned}
& \text { Livelihood assets of the respondents } \\
& \text { (dependent variable) }
\end{aligned}
$$

$\mathrm{i}=$ Different livelihood assets of the respondents [land for agriculture (hectares); livestock keeping (counts); maize farming $(\mathrm{Kg})$; Horticulture $(\$)$; Bee keeping (\$); Poultry farming (Number of birds); fruit production (\$); Charcoal production (\$), fish farming (number of fishes);

$\mathrm{X}_{1}=$ Average annual rainfall (millimetres);

$\mathrm{X}_{2}=$ Average annual maximum Temperature (degree centigrade);

$\mathrm{e}_{\mathrm{i}}=$ Error term

\section{RESULTS}

\subsection{Socio-economic Characteristics of the Rural Populace in Marigat and Mogotio, Baringo County, Kenya}

The age distribution of the respondents showed that majority $(38.46 \%)$ of the rural population were within the age bracket of $41-50$ years while $2.96 \%$ of the rural population were older than 60 years in age. From table $1 \mathrm{~b}$, the household heads were mainly pastoralists (45.27\%), followed by agro-pastoralist (35.5\%), Business $(10.36 \%)$ and least were of employed individuals $(8.88 \%)$. The spouses were mainly agropastoralists as reputed by $82.84 \%$ of the sampled populace in Marigat and Mogotio as shown in Table 1.

\subsection{Trend of Climate Variability in Baringo County, Kenya}

The result in Fig. 1 showed that $93.5 \%$ of the rural population reputed that there is a decrease in rainfall in the county in the last raining season while $94.1 \%$ of the respondents averred that there is increase in temperature in the study area.

Rainfall Trend: The trend analysis of the annual rainfall from 1985 to 2016 shows fluctuations with constant decrease and increase in annual rainfall (Fig. 2). This volume of rainfall declined from 80.1 millimetres in 1985 to 58.7 millimetres of rainfall in 1986, and increased to 104.3 millimetres in 1988. Before decreasing again to 76.3 millimetres in 1991. However there have been a constant fluctuation in the volume of rainfall in the area since 2000. A $6.31 \%$ variation in volume of rainfall in the area was explained by changes in time. This is shown in Fig. 2. 
Temperature Trend: The trend analysis of the temperature from 1985 to 2016 showed fluctuations with increased temperature (Fig. 3). The maximum temperature of the area increased from $30.8^{\circ} \mathrm{C}$ in 1985 to $31.5^{\circ} \mathrm{C}$ in 1987 , but dropped to $30.3^{\circ} \mathrm{C}$ in 1989 before it vaults up to $31^{\circ} \mathrm{C}$ in 1991 . The maximum temperature of the area fluctuated steadily between $1992\left(30.7^{\circ} \mathrm{C}\right)$

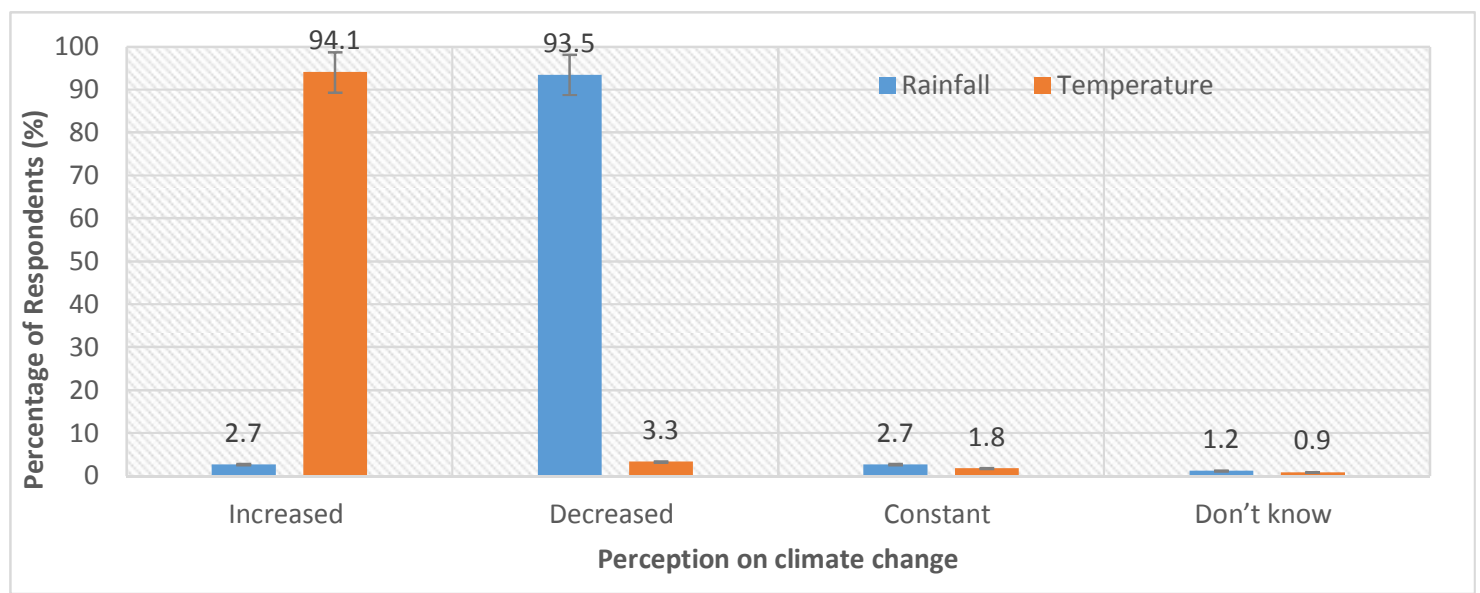

Fig. 1. Perception on climate variability in Baringo County, Kenya

Table 1a. Socio-economic characteristics of the sampled rural populace in Marigat and Mogotio, Baringo County

\begin{tabular}{lll}
\hline Distribution of Socioeconomic characteristics & Frequency & Percentage \\
\hline Gender & 206 & \\
Male & 132 & 60.95 \\
Female & 38 & 39.05 \\
Age of respondents & 119 & 11.24 \\
$18-30$ & 130 & 35.21 \\
$31-40$ & 41 & 38.46 \\
$41-50$ & 10 & 12.13 \\
$51-60$ & & 2.96 \\
$>60$ & 64 & \\
Level of Education & 103 & 18.93 \\
No School & 128 & 30.47 \\
Primary & 33 & 37.87 \\
Secondary & 10 & 9.76 \\
Tertiary/College & & 2.96 \\
University & 60 & \\
Marital Status & 185 & 17.75 \\
Single & 25 & 54.73 \\
Married & 25 & 7.40 \\
Divorced & 43 & 7.40 \\
Separated & & 12.72 \\
Widowed & 169 & \\
No. of Family Members & 149 & 50.00 \\
$1-5$ & 15 & 44.08 \\
$6-10$ & 2 & 4.44 \\
$11-15$ & 3 & 0.59 \\
$16-20$ & 0.89 \\
$>$ 20 & &
\end{tabular}

Source: Field Survey Data, 2017 
Table 1b. Socio-economic characteristics of the sampled rural populace in Marigat and Mogotio, Baringo County (continued)

\begin{tabular}{lll}
\hline Socioeconomic characteristics & Frequency & Percentage \\
\hline Occupation of HH Head & & \\
Pastoralist & 153 & 45.27 \\
Agro-Pastoralist & 120 & 35.50 \\
Business & 35 & 10.36 \\
Employed & 30 & 8.88 \\
Occupation of Spouse & 16 & 4.73 \\
Pastoralist & 280 & 82.84 \\
Agro-Pastoralist & 30 & 8.88 \\
Business & 12 & 3.55 \\
Employed & & \\
Do you have Land & 315 & 93.20 \\
Yes & 23 & 6.80 \\
No & & \\
If Yes, was it & 60 & 17.75 \\
Bought & 59 & 17.46 \\
Rented & 9 & 2.66 \\
Issued by Govt. Ranch & 3 & 0.89 \\
Issued by National Irrigation Board & 207 & 61.24 \\
Issued by Government & 338 & 100.00 \\
Total & & \\
Size of the Land (ha) & 145 & 42.90 \\
$1-3$ & 88 & 26.04 \\
$3.1-6.0$ & 24 & 7.10 \\
$6.1-9.0$ & 25 & 7.40 \\
$9.1-12.0$ & 56 & 16.57 \\
$>12.0$ & 338 & 100.00 \\
Total & 2017 & \\
\hline
\end{tabular}

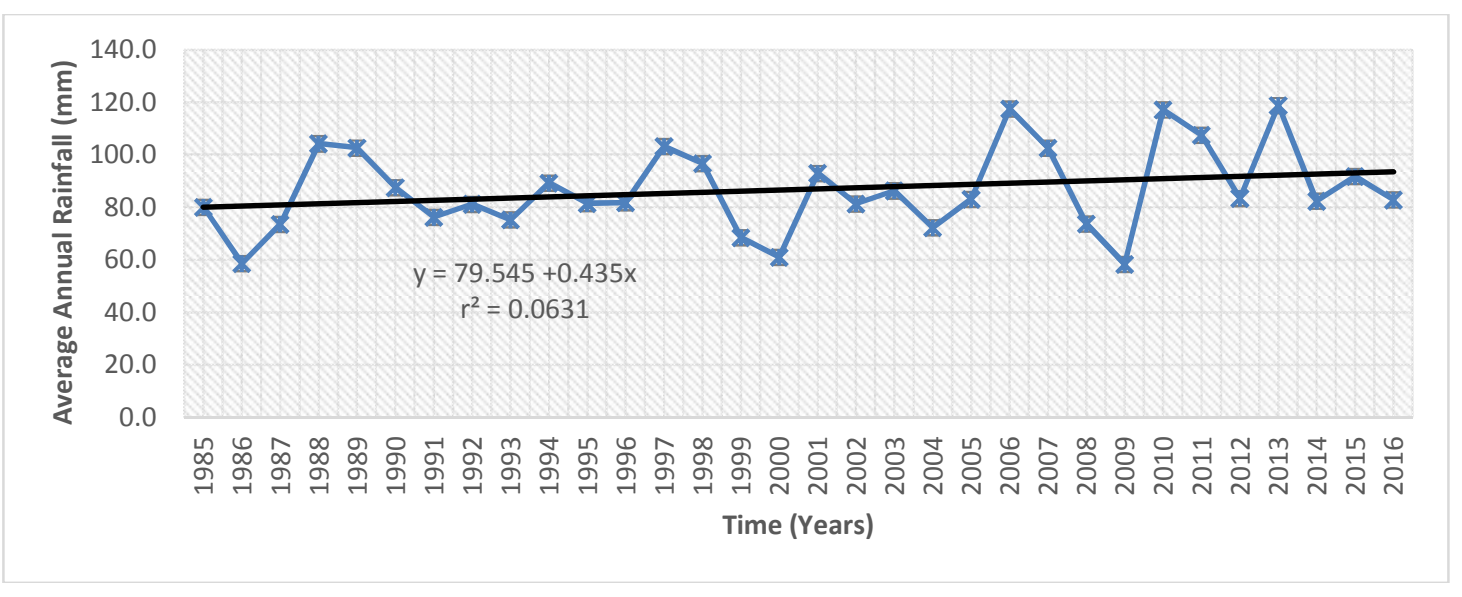

Fig. 2. Mean variation in the annual rainfall $(\mathrm{mm})$ in Baringo County, Kenya

and $2001\left(31.4^{\circ} \mathrm{C}\right)$ and increased to $30.1^{\circ} \mathrm{C}$ in 2004. The maximum temperature of the area vaults up to $32^{\circ} \mathrm{C}$ in 2015 and $32.2^{\circ} \mathrm{C}$ in 2016 . A $10.2 \%$ variation in the maximum temperature in the area was explained by changes in time. A unit change in time causes the maximum temperature to slightly change by $0.016^{\circ} \mathrm{C}$. The people's perceptions on temperature variations in the studied area were in line with the climatic data records, as shown in Fig. 3. 


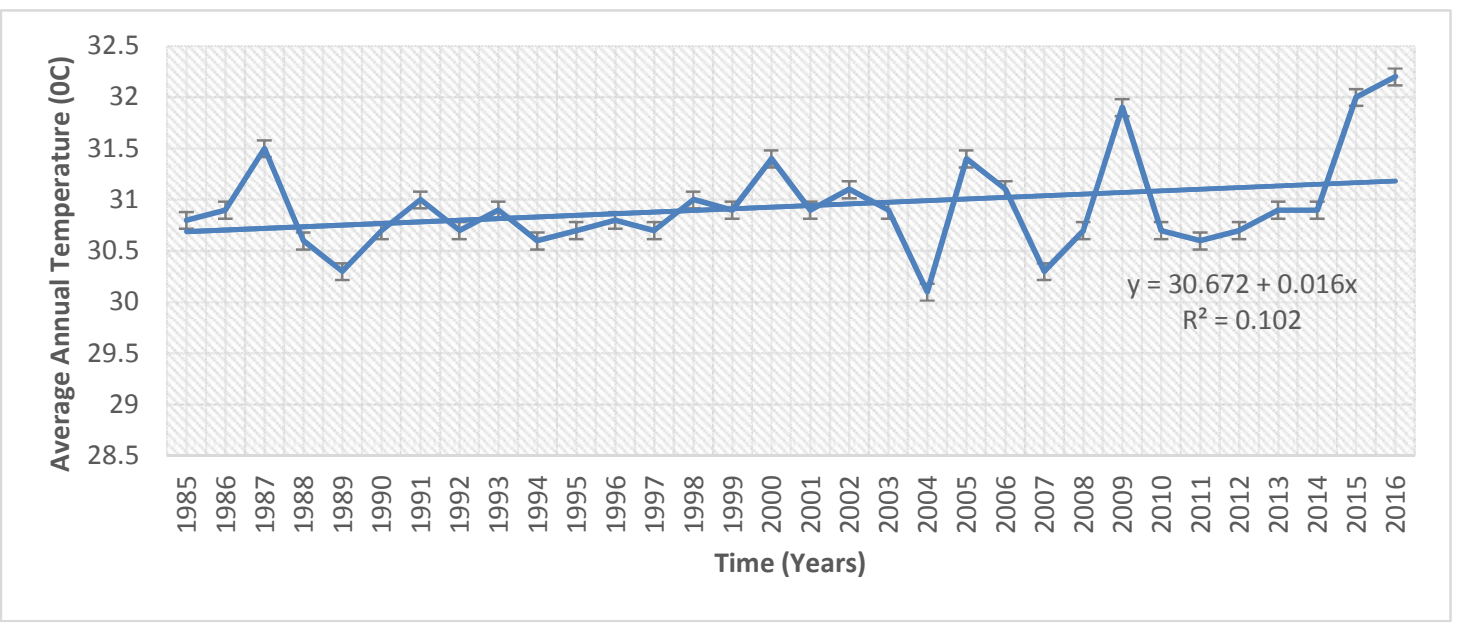

Fig. 3. Mean Variations in the annual temperature in Baringo County, Kenya

From the study, preponderance of the respondents reported that over time, the temperature has increased radically while rainfall has decreased. The inconsistency as reported by the respondents in rainfall decrease and increase may have been fully buttressed with the average annual rainfall in the last 31 years (Fig. 2) and the rise in temperature as reported by the respondents, could have been as a result of consistent increase in temperature from 2014 to 2016 (Fig. 3).

\subsection{Effects of Climate Variability on Livelihood Assets}

This shows the Ordinary least square multiple regression result of the effect of climate change variability on livelihood assets of rural populace in Marigat and Mogotio. For the land model, the value of the coefficient of multiple determinations $\left(R^{2}\right)$ was 0.612 , implying that about $61.2 \%$ of the variations in the value of land for agriculture among rural populace explained by the regressors (independent variables) included in the model. The F-statistic of (18.533) was significant at $P<0.05$, implying that the entire model was significant. The result showed that rainfall and temperature significantly influenced the value of land for agriculture in Baringo County. The coefficient of rainfall was positive and significant at 5\% indicating that increase in rainfall leads to an increase in the value of land for agriculture. However, the coefficient of temperature was negative and significant at $1 \%$ respectively, indicating that increase in temperature leads to a decrease in the value of land for agriculture. The value of the coefficient of multiple determinations $\left(R^{2}\right)$ for maize farming model was 0.609 , implying that about $60.9 \%$ of the variations in maize farming was explained by the regressors (independent variables) included in the model. The F-statistic of (13.536) was significant at $\mathrm{P}<0.05$. The value of the coefficient of multiple determinations $\left(R^{2}\right)$ for horticulture model was 0.554 , implying that about $55.4 \%$ of the variations in horticulture was explained by the regressors (independent variables) included in the model. The F-statistic of (13.536) was significant at $P<0.05$. The bee keeping model shows that the value of the coefficient of multiple determinations $\left(R^{2}\right)$ was 0.564 , implying that about $56.4 \%$ of the variations in bee keeping was explained by the regressors (independent variables) included in the model. The F-statistic of (21.840) was significant at $P<0.05$. The poultry farming model shows the value of the coefficient of multiple determinations $\left(R^{2}\right)$ was 0.481 , implying that about $48.1 \%$ of the variations in poultry farming was explained by the regressors (independent variables) included in the model. The F-statistic of (9.902) was significant at $P<0.05$, implying that the entire model was significant. The fruit production model shows the value of the coefficient of multiple determinations $\left(R^{2}\right)$ was 0.592 , implying that about $59.2 \%$ of the variations in fruit production was explained by the regressors (independent variables) included in the model. The F-statistic of (11.837) was significant at $P<0.05$. For charcoal production model, the value of the coefficient of multiple determinations $\left(R^{2}\right)$ was 0.638 , implying that about $63.8 \%$ of the variations in charcoal production was explained by the regressors (independent variables) included in the model. The F-statistic of (9.902) was significant at $\mathrm{P}<$ 
0.05. In this fish farming model, the value of the coefficient of multiple determinations $\left(R^{2}\right)$ was 0.428 , implying that about $42.8 \%$ of the variations in fish farming was explained by the regressors (independent variables) included in the model. The F-statistic of (9.902) was significant at $P<0.05$. The multiple regression results of the effect of climate change variability on livelihood assets of rural populace in Baringo County, Kenya is presented in Table 2.

\subsection{Sources of Information on Climate Change and Variability among Rural Populace in Baringo County}

The result showed that majority $(78.7 \%)$ of the rural populace in study area had access to climate change and variability information while $21.3 \%$ of them had no access to such information. The source of information for climate change and variability information in the study area showed that $41.4 \%$ of the respondents got informed of climate change and its variability through the media. Other sources of information on climate change include: other farmers (33.1\%), Schools (10.5\%), Government Officer $(7.9 \%)$, and Non-Governmental Organization $(6.4 \%)$. Majority of the rural populace $(57.9 \%)$ asserted that climate change information helps them to ensure healthy livestock keeping. The information helped $22.9 \%$ of the respondents to increase their farm yields, $14.3 \%$ of the respondents to ensure water availability during the dry season, while $3.0 \%$ and $1.9 \%$ of the respondents to ensure soil moisture and soil fertility respectively. This is presented in Table 3 .

\subsection{Extent of Climate Variability and Its Effects in Baringo County}

In table 4 below, climate variability to a high extent affected the rural populace as Drought and wildfire occurrence increased, crop and livestock pests and diseases, drying water bodies. The study showed that the respondents accepted five (5) out of seven (7) statements bordering on the extent climate variability affects the people. In Baringo, climate variability to a high extent affects the rural populace by causing drought $(X=3.78)$, crop pest and diseases $(X=$ $3.65)$, livestock pest and diseases $(X=3.70)$; cases of human diseases $(X=4.01)$ and drying of water bodies $(X=3.53)$ with an overall mean score of 3.28. This implies that there is drought, incidence of crop and livestock pest and diseases, cases of human diseases and drying of water bodies due to climate variability in the rural area of Baringo County.

Table 2. Ordinary least square multiple regression results of the effect of climate variability on livelihood assets of rural populace in Marigat and Mogotio, Baringo County

\begin{tabular}{|c|c|c|c|c|c|c|c|}
\hline \multicolumn{2}{|c|}{ Models } & \multirow{2}{*}{$\begin{array}{l}\text { Constant } \\
5.265 \\
(2.417)^{\star *}\end{array}$} & \multirow{2}{*}{$\begin{array}{l}\text { Rainfall } \\
1.430 \\
(2.621)^{\star *}\end{array}$} & \multirow{2}{*}{$\begin{array}{l}\text { Temperature } \\
-0.121 \\
(-3.587)^{\star \star \star}\end{array}$} & \multirow{2}{*}{$\begin{array}{l}\mathbf{R}^{2} \\
0.612\end{array}$} & \multirow{2}{*}{$\begin{array}{l}\text { Adj. } \mathbf{R}^{2} \\
0.593\end{array}$} & \multirow{2}{*}{$\begin{array}{l}\text { F- } \\
\text { statistic } \\
18.533^{\star * \star}\end{array}$} \\
\hline 1 & Land for agriculture & & & & & & \\
\hline 2 & Livestock keeping & $\begin{array}{l}6.309 \\
(2.841)^{\star * *}\end{array}$ & $\begin{array}{l}1.184 \\
(2.112)^{\star \star}\end{array}$ & $\begin{array}{l}-2.028 \\
(-3.419)^{\star * *}\end{array}$ & 0.613 & 0.598 & $12.282^{* * *}$ \\
\hline 3 & Maize farming & $\begin{array}{l}8.419 \\
(2.441)^{\star *}\end{array}$ & $\begin{array}{l}1.048 \\
(2.545)^{\star *}\end{array}$ & $\begin{array}{l}-0.993 \\
(-3.379)^{\star * *}\end{array}$ & 0.609 & 0.583 & $13.536^{* * *}$ \\
\hline 4 & Horticulture & $\begin{array}{l}8.433 \\
(2.673)^{* *}\end{array}$ & $\begin{array}{l}0.792 \\
(2.101)^{\star *}\end{array}$ & $\begin{array}{l}0.048 \\
(0.760)\end{array}$ & 0.554 & 0.438 & $7.690^{\star * *}$ \\
\hline 5 & Bee keeping & $\begin{array}{l}9.030 \\
(3.215)^{\star * *}\end{array}$ & $\begin{array}{l}4.058 \\
(0.809)^{\star * *}\end{array}$ & $\begin{array}{l}-0.037 \\
(-0.676)^{\star * *}\end{array}$ & 0.564 & 0.541 & $21.840^{* * *}$ \\
\hline 6 & Poultry farmig & $\begin{array}{l}9.635 \\
(3.576)^{\star \star *}\end{array}$ & $\begin{array}{l}-0.439 \\
(-2.485)^{\star *}\end{array}$ & $\begin{array}{l}-1.133 \\
(-1.941)^{*}\end{array}$ & 0.481 & 0.465 & $9.902^{* * *}$ \\
\hline 7 & Fruit production & $\begin{array}{l}5.222 \\
(3.983)^{\star * *}\end{array}$ & $\begin{array}{l}-1.067 \\
(-3.158)^{\star \star *}\end{array}$ & $\begin{array}{l}-1.024 \\
(-2.551)^{\star \star}\end{array}$ & 0.592 & 0.571 & $11.837^{* * *}$ \\
\hline 8 & $\begin{array}{l}\text { Charcoal } \\
\text { production }\end{array}$ & $\begin{array}{l}6.125 \\
(2.712)^{\star \star *}\end{array}$ & $\begin{array}{l}-1.042 \\
(-3.105)^{* * *}\end{array}$ & $\begin{array}{l}1.304 \\
(2.128)^{* *}\end{array}$ & 0.638 & 0.611 & $12.645^{\star \star *}$ \\
\hline 9 & Fish farming & $\begin{array}{l}7.012 \\
(3.148)^{* * *}\end{array}$ & $\begin{array}{l}1.080 \\
(3.016)^{\star * *}\end{array}$ & $\begin{array}{l}0.039 \\
(1.255)\end{array}$ & 0.428 & 0.405 & $9.185^{\star * \star}$ \\
\hline
\end{tabular}

Source: Author's computation from field survey data, 2017

Note: ${ }^{* *},{ }^{* *}$ and ${ }^{*}$ represents $1 \%, 5 \%$ and $10 \%$ levels of significance. 
Table 3. Sources of information on climate change and variability among the rural populace

\begin{tabular}{|c|c|c|}
\hline Sources of information on climate change and variability & Frequency & Percentage \\
\hline \multicolumn{3}{|l|}{ Access to climate change $\&$ variability information } \\
\hline Yes & 266 & 78.70 \\
\hline No & 72 & 21.30 \\
\hline \multicolumn{3}{|l|}{ Sources of information } \\
\hline Govt. officer & 21 & 7.9 \\
\hline NGO & 17 & 6.4 \\
\hline Other Farmers & 88 & 33.1 \\
\hline Media & 110 & 41.4 \\
\hline Groups & 2 & 0.8 \\
\hline Schools & 28 & 10.5 \\
\hline \multicolumn{3}{|l|}{ The frequency of receiving information } \\
\hline Weekly & 40 & 15.0 \\
\hline Monthly & 90 & 33.8 \\
\hline Quarterly & 102 & 38.3 \\
\hline Half yearly & 20 & 7.5 \\
\hline Annually & 12 & 4.5 \\
\hline$>1$ year & 2 & 0.8 \\
\hline \multicolumn{3}{|l|}{ Is the information useful? } \\
\hline Yes & 250 & 94.0 \\
\hline No & 16 & 6.0 \\
\hline \multicolumn{3}{|l|}{ How the information helped } \\
\hline Water availability & 38 & 14.3 \\
\hline Increased farm yields & 61 & 22.9 \\
\hline Healthy livestock & 154 & 57.9 \\
\hline Soil moisture & 8 & 3.0 \\
\hline Soil fertility & 5 & 1.9 \\
\hline
\end{tabular}

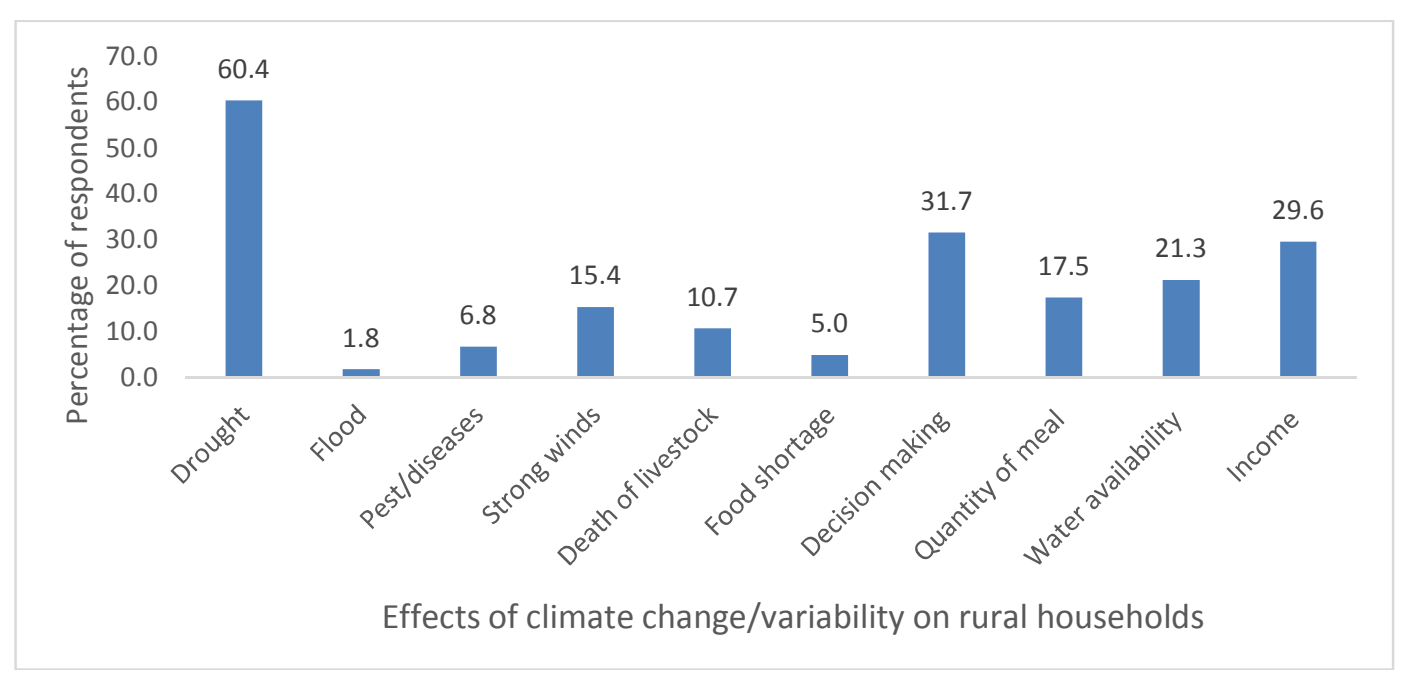

Fig. 4. Areas climate change/variability affected the rural populace in Baringo County

The result below shows that drought mostly affects the rural populace as reported by $60.4 \%$ of the respondents. This was followed by quantity of their meal (31.7\%), and income (29.6\%) whereas, flooding was the least area in which climate change affected the rural populace as reported by $1.8 \%$ of the respondents. This infers that drought is the major climate variability induced problem facing the people of Baringo County, Kenya.

The different areas in which climate variability mostly affects the respondents in Baringo county, Kenya is presented in Fig. 4. 
Table 4. Mean rating of the respondents on the extent of the effect of climate variability in Baringo county

\begin{tabular}{|c|c|c|c|c|c|c|c|}
\hline Effects of climate variability & Always & Very often & Sometimes & Rarely & Never & Mean Score & S.D \\
\hline Drought & $51(15.09)$ & $164(48.52)$ & $119(35.21)$ & $4(1.18)$ & - & 3.78 & 0.81 \\
\hline Flood & $4(1.18)$ & $11(3.25)$ & 164(48.52) & $121(35.80)$ & $38(11.24)$ & 2.47 & 0.60 \\
\hline Wild fire & - & $6(1.78)$ & $30(8.88)$ & $205(60.65)$ & $97(28.70)$ & 1.84 & 0.49 \\
\hline Crop pests \& diseases & $45(13.31)$ & $141(41.72)$ & $144(42.60)$ & $6(1.78)$ & $2(0.59)$ & 3.65 & 0.74 \\
\hline Livestock pests \& diseases & $44(13.02)$ & $152(44.97)$ & $137(40.53)$ & $5(1.48)$ & - & 3.70 & 0.78 \\
\hline Cases of human diseases & $127(37.57)$ & $93(27.51)$ & 114(33.73) & $4(1.18)$ & - & 4.01 & 0.80 \\
\hline Drying water bodies & $37(10.95)$ & $152(44.97)$ & $111(32.84)$ & $29(8.58)$ & $9(2.66)$ & 3.53 & 0.71 \\
\hline Overall mean score & & & & & & 3.28 & 0.70 \\
\hline Number of respondents & & & & & & 3.38 & \\
\hline Decision cut point & & & & & & 3.00 & \\
\hline
\end{tabular}

$S . D=$ Standard deviation of the mean score

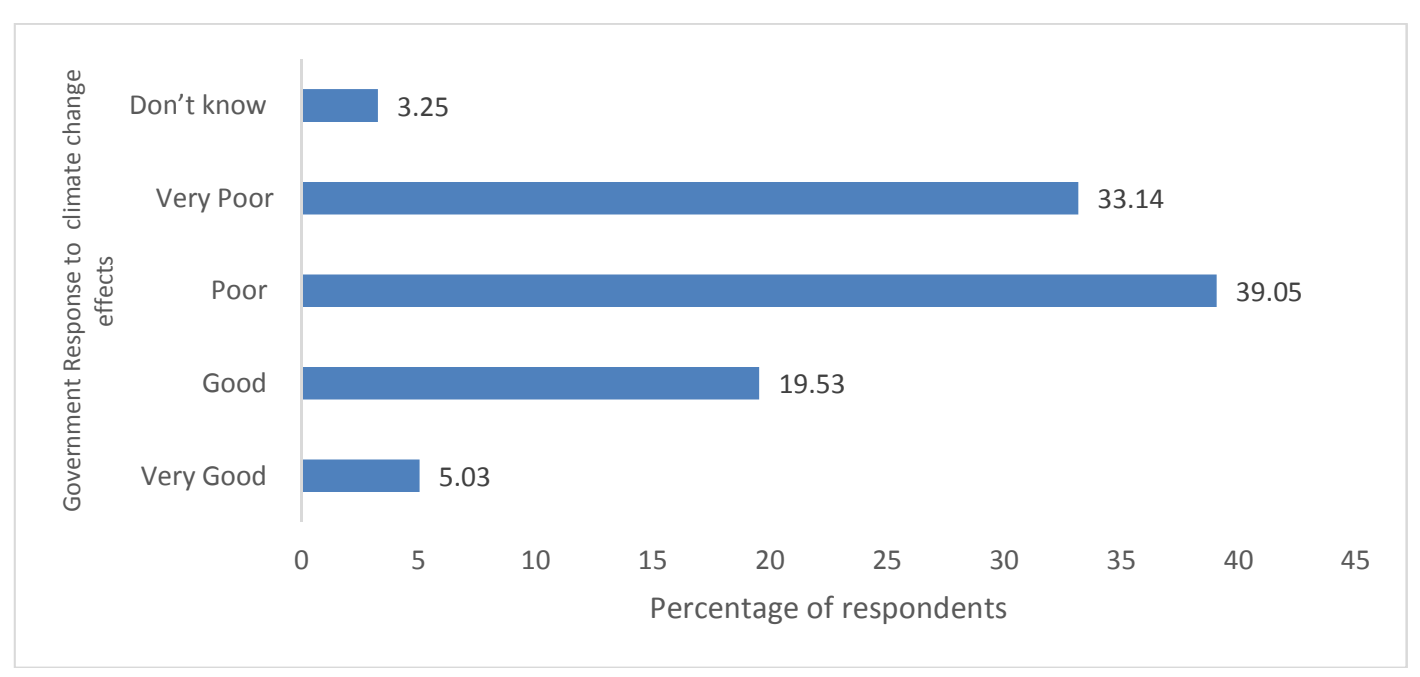

Fig. 5. Perception of government response to climate variability in Baringo County, Kenya 
In Fig. 5, government response to the challenges (lack of water, food security, poor harvest, diseases etc) of climate variability, showed that preponderance $(39.05 \%)$ of the rural respondents in Baringo County, Kenya reputed that government response is poor, followed by $33.14 \%$ of them that rated the response to be very poor. Only $5.03 \%$ of the respondents in Baringo County asserted that the response of the government in the areas climate variability affected them was very good. This implies that there is poor government response to climate variability in the study area.

\section{DISCUSSION}

Socio-economic characteristics of the sampled rural populace in Baringo County, Kenya: From the study it was observed that most of the respondents were youth, which may be due to the average working age of people in Kenya, as teenagers and youths may still be in schools outside the studied counties and the older ones may have retired from participating in some economic activities due to age. This, according to [13] is contrary to the average age of a Kenyan farmer of 57 years. Majority of the populace in Baringo County are primary and secondary school graduates, with a very low percentage having attained a tertiary education. These results are similar to those in the report of [14] that showed Baringo County has 656 primary schools with remarkable improvements in enrolments and 125 secondary schools. A total of $16 \%$ of the population have a secondary level of education or above, while those with primary education are $48 \%$ and $36 \%$ of the population have no formal education. Other researchers in Kenya have also reported similar observations of low levels of education and attributed it to high levels of dropout from secondary schools, as noted in a report published by [15]. Majority of the school drop-outs are due to lack of school fees, or the need to assist at home during extreme climatic conditions (drought) and the resultant effect of this action is the high level of illiteracy as well as early marriages. Many of them end up working as casual labourers in construction companies, or in the transportation sector (popularly known as bodaboda).

The household heads were observed to be mainly pastoralists and agro-pastoralists as it is believed that people make livelihood choices according to the level of their household assets or availability of infrastructure in their community [16]. The sub-counties sampled do not have a wide range of livelihood options as most of them indicated to have little or no significant secondary livelihood sources. This implies that these counties will have reduced resilience to the effects of climate variability due to lack of wide range of livelihood options. However, from the observation in the study, the persons sampled largely accept they own some portion of land, of which was issued to them by government.

\subsection{Effects of Climate Variability on Livelihood Assets}

The results of the study clearly show that the variability in temperature and rainfall affected general economic activities of the counties at every level of statistical significance. These results are supported by [17] who has shown that farmers' incomes have a positive relationship with the climate variables and that adoption of agricultural technologies may in a long way help reduce the impact of climate on livelihood assets. [18] also reported that consistent increase in climate variables impact on, not just ecosystems, but most likely will alter the economic and physical factors that determine their livelihood strategies and resilience. [19] predicted that the effect of potential climate change on economic and farming sector would have serious negative consequences for rural livelihoods and it could lead to a decrease in income. In addition, [20] said the consequences, for instance, of increased temperatures may lead to increase in pests and pathogens that affect key species of plants and animals.

The results show that rainfall and temperature significantly influenced the value of land for agriculture in Baringo County. The coefficient of rainfall was positive and significant at $5 \%$ indicating that increase in rainfall leads to an increase in the value of land for agriculture in Baringo. However, the coefficient of temperature was negative and significant at $1 \%$ respectively, indicating that increase in temperature leads to a decrease in the value of land for agriculture in Baringo. This may be due to soil dryness and death of grasses as that may not support crop cultivation and livestock rearing respectively. Decrease in rainfall will cast a doubt on fodder production for livestock feeding. At high temperature, fodder plants die and result in reduction in livestock feed. Also, high temperature increases the body temperature of most livestock and often results in death of animals. This will negatively affect the dependency on livestock keeping as a livelihood 
asset among the rural populace. Increase in adequate and timely annual rainfall enables plants to grow and produce fruits. Increase in fruit production will lead to an increase in quantity of fruits that can be sold for income generation. [21] found rainfall to be directly related to crop output and posited that adequate and timely rainfall was required for increased crop production. This suggests that variability in rainfall will affect the adequate and timely rainfall required for plant fruiting. As a result, fruits production as a livelihood asset of rural populace in Baringo County, Kenya decreases with increase in rainfall variability.

\subsection{Sources of Information on Climate Change and Variability among Rural Populace in Baringo County}

From the study, the populace of the Baringo County was found to be up to date and are well informed in the areas of climate change and variability, as the source was majorly from media group and farmers in the community and so far the information helped them mainly in keeping their livestock healthy. Thus, it is not likely that rural dwellers may regard occasions in their environment as normal, so they may readily link them to climate variability. This result collaborates with the study conducted in the Sahel [22] where it was found out that farmers were aware of climate variability. These results were similar to [23] who reported that majority $(81 \%)$ of the respondents received weather information through media while $17 \%$ received through training, and 9\% from agricultural officer and concluded that farmers' access to information on climate variability is likely to enhance their probability to perceive climate variability, and hence adoption of new technologies and take-up adaptation techniques.

\subsection{Extent of Climate Variability and Its Effects in Baringo County}

The study was able to establish that high variability in climate conditions affected the rural population in Kenya majorly in the areas of drought, income and decision making, also by perception very high percentage of the people believes so. These results of the study are confirmed by [24] report which stated that climate change may lead to poverty, while technology, capital and policy have the potential to seriously impede a community's ability to implement adaptation options by limiting the range of possible responses and interventions. A study by [23] indicated that farmers with access to extension services are likely to understand climate variability because extension services provide information about climate and weather. On the other hand, there is an argument by [25] that indicated that knowledge about climate variability is low among rural farmers of the Niger Delta region of Nigeria. This lack of knowledge on climate variability is considered by [25] to be one of the major constraints to climate variability adaptation by farmers in the Niger Delta. Recognition and knowledge of climatic conditions and variability are critical because adaptation to climate variability requires that farmers first recognize that there is climate variability, and then identify useful adaptation strategies and implement them [26]. This has also been indicated by [27] who showed that well-informed farmers are capable of making appropriate changes to adapt their agricultural production to climate variability.

\section{CONCLUSION}

In conclusion, this study has shown that climate has a major impact directly or indirectly on rural livelihoods. Rainfall and temperature were the climatic variables that majorly affected the health, wealth and normal activities of the livestock, crops and people of Baringo County, Kenya. The ability to integrate new information would facilitate learning and increase adaptive capacity, which is particularly important if variability increases in the future. An increase in adaptive capacity is therefore critical in contributing to future household resilience that could increase the sustainability of both livelihoods and information networks. Based on the findings of this study, the extension personnel should be trained and motivated in order to disseminate relevant information to farmers on how to diversify their livelihood in order to cope with climate variability.

\section{ACKNOWLEDGEMENTS}

This research has been funded by UK aid from the UK government. The author(s) wish to acknowledge the kind support of Association of Commonwealth Universities (ACU), DFID, VITAE and African Academy of Sciences (AAS) under the coordination of CIRCLE (Climate Impact Research Capacity and Leadership Enhancement), who awarded a research scholarship grant to Ezenwa Lilian I. to carry out this Research in Kenya. 


\section{COMPETING INTERESTS}

Authors have declared that no competing interests exist.

\section{REFERENCES}

1. Inter-governmental Panel for Climate Change (IPCC). Climate Change 2007: Impacts, Adaptation and Vulnerability. In: Parry ML, Canziani OF, Palutikof JP, van der Linder PJ, Hanson CE (eds.), and Contribution of Working Group II to the IPCC fourth assessment report. Cambridge University Press, Cambridge; 2007.

2. DFID. Climate change in Africa. Key Sheet Series No. 10; 2004.

3. Antwi-Agyei P, Stringer LC, Dougill AJ. Livelihood adaptations to climate variability: Insights from farming households in Ghana. Regional Environ. Change. 2014;14(1):3-14.

4. Agbo FU, Arua RN, Okonkwo EA. Effects of climate variability on the choices of livelihood among farm households in Anambra State, Nigeria. African Journal of Agricultural Research. 2015;10(44):41344141.

5. Ziervogel G, Calder R. Climate variability and rural livelihoods: Assessing the impact of seasonal climate forecasts in Lesotho. Area. 2003;35(4):403-417.

6. Gebru GW, Beyene F. Rural household livelihood strategies in drought-prone areas: A case of Gulomekeda District, eastern zone of Tigray National Regional State, Ethiopia. J. Dev. Agric. Econ. 2012;4(6):158-168.

7. Kalinda $\mathrm{T}$, Langyintuo A. Livelihood strategies, shocks and coping mechanisms among rural households in Southern Zambia. Curr. Res. J. Soc. Sci. 2014; 6(4):120-133.

8. Nkoya EJ, Pender $P$, Jagger D, Sserunkuuma C, Kaizzi HS.. Strategies for sustainable land management and poverty reduction in Uganda Research Report 133 International Food Policy Research Institute (IFPRI) Washington. D.C.; 2004.

9. Herrero M, Thornton PK, Gerber P, Reid RS. Livestock, livelihoods and the Environment: Understanding the trade-offs. Current Opinion in Environmental Sustainability. 2009;1:111-120.
10. Bebbington A. Capitals and capabilities: A framework for analyzing peasant viability, rural livelihoods and poverty. World Development. 1999;27(12):20212044.

11. KNBS. 2009 Kenya population and housing census, Volume I A; Population by Administrative Units, Kenya National Bureau of Statistics, Nairobi, Kenya; 2009.

12. Wasonga VO, Nyariki DM, Ngugi RK. Assessing socio-ecological change dynamics using local knowledge in the semi-arid lowlands of Baringo District, Kenya. Environmental Research Journal. 2011;5(1):11-17.

13. Momanyi $\mathrm{S}$, Mutai $\mathrm{N}$, Bii J. Attracting young people to farming. Agfax. Reporting Science in Africa; 2012.

14. Exploring Kenya's Inequality (Baringo County), KNBS. Baringo County Baseline Analysis - KIRA; 2009.

Available:http://knbs.or.ke/countydata.php (Thursday, 5th July, 2017)

15. Glennerster R, Kremer M, Mbiti I, Takavarasha K. Access and quality in the Kenyan education system: A review of the progress, challenges and potential solutions. Prepared for Office of the Prime Minister of Kenya; 2011.

16. Gebru GW, Beyene F. Rural household livelihood strategies in drought-

Prone areas: A case of Gulomekeda District, eastern zone of Tigray National Regional State, Ethiopia. J. Dev. Agric. Econ. 2012;4(6):158-168.

17. Knowler D, Bradshaw B. Farmers' adoption of conservation agriculture: A review and synthesis of recent research. Food Policy. 2007;32(1).

18. Chia EL, Somorin OA, Sonwa DJ, Tiani AM. Local vulnerability, forest communities and forest carbon conservation: case of southern Cameroon. International Journal of Biodiversity and Conservation. 2013; 5(8):498-507.

19. Turpie J, Winkler $H$, Spalding-Fecher $R$, Midgley $G$. Economic impacts of climate change in South Africa: A preliminary analysis of Unmitigated Damage Costs, Southern Waters Ecological Research \& Consulting \& Energy and Development Research Centre, University of Cape Town, Cape Town; 2002.

20. Naidoo S, Davis C, Archer van Garderen E. Forests, rangelands and climate change in Southern Africa. Forests and Climate 
Change Working Paper No 12, FAO, Rome; 2013.

21. Ayinde OE, Ajewole OO, Ogunlade I, Adewumi MO. Empirical analysis of agricultural production and climate change: a case study of Nigeria. Journal of Sustainable Development. 2010;12(6). ISSN: $1520-5509$

22. Mertz O, Mbow C, Reenberg A, Diouf A. Farmers' perceptions of climate change and agricultural adaptation strategies in rural Sahel. Environmental Management. 2009;43(1):804-816.

23. Gbetibouo GA. Understanding farmers' perceptions and adaptations to climate change and variability: The case of the Limpopo Basin, South Africa. IFPRI Discussion Paper No. 00849; 2009.

Cited 3 May, 2009.

24. IPCC. Climate Change 2001: Impacts, Adaptation, and Vulnerability: Contribution of Working Group II to the Third Assessment Report of the IPCC, Cambridge University Press. 2001;P435458.

25. Nzeadibe TC, Egbule CL, Chukwuone NA, Agu VC. Climate change awareness and adaptation in the Niger Delta region. African Technology Policy Studies Network working Paper Series No 57. Nairobi; 2011.

26. Maddison D. The perception of and adaptation to climate change in Africa. CEEPA Discussion Paper No. 10. Centre for Environmental Economics and Policy in Africa, University of Pretoria, South Africa; 2006.

27. Antle JM. Agriculture and the food system. Adaptation to climate change. Resources for the future. RFF Report. 4-7; 2009.

(c) 2018 Ezenwa et al.; This is an Open Access article distributed under the terms of the Creative Commons Attribution License (http://creativecommons.org/licenses/by/4.0), which permits unrestricted use, distribution, and reproduction in any medium, provided the original work is properly cited.

Peer-review history:

The peer review history for this paper can be accessed here: http://www.sciencedomain.org/review-history/24851 